TITLE:

\title{
Tumors attenuating the mitochondrial activity in T cells escape from PD-1 blockade therapy(Abstract_要旨)
}

$\operatorname{AUTHOR}(S)$ :

Alok, Kumar

\section{CITATION:}

Alok, Kumar. Tumors attenuating the mitochondrial activity in T cells escape from PD-1 blockade therapy. 京都大学, 2020, 博士(医学)

ISSUE DATE:

2020-07-27

URL:

https://doi.org/10.14989/doctor.k22694

\section{RIGHT:}

(C) 2020 eLife Sciences Publications Ltd. This is not the published version. Please cite only the published version. この論文は出版社版でありません。引用の際には出版社版をご確 認ご利用ください。https://elifesciences.org/articles/52330 (DOI: 10.7554/eLife.52330) 


\begin{tabular}{|l|l|l|l|}
\hline 京都大学 & 博士（医 学 ） & 氏名 & Alok Kumar \\
\hline 論文題目 & $\begin{array}{l}\text { Tumors attenuating the mitochondrial activity in T cells escape from } \\
\text { PD-1 blockade therapy } \\
(\mathrm{T} \text { 細胞ミトコンドリアを抑制するがんはPD-1 阻害がん免疫治療から逃避する) }\end{array}$ \\
\hline (論文内容の要旨)
\end{tabular}
(論文内容の要旨)

Immune checkpoint (especially PD-1) blockade-based immunotherapy has revolutionized the cancer treatment because of improved survival, less side-effects, and applicability to tumors of all stages and types. Despite great success, a significant fraction of patients remains unresponsive to PD-1 blockade therapy. To rescue unresponsive patients, the mechanism of unresponsiveness to PD-1 blockade therapy must be elucidated. In this work, murine model was used understand the reasons of unresponsiveness. First, all murine cancer cell lines were classified into responsive and unresponsive groups in mouse model using anti-PD-L1 mAb treatment to block the PD-1/PD-L1 axis. MC38 (colon carcinoma), GL261 (glioblastoma) were classified as responsive while LLC (lewis lung carcinoma) as unresponsive in C57BL/6 background of mice. Similarly, MethA (fibroscarcoma) was classified as responsive and CT26 (colon carcinoma) as unresponsive in BALB/c background. Further, difference in immune responses were compared for hosts bearing responsive or unresponsive tumor with or without PD-1 blockade condition. Both the total lymphocytes and the effector memory $\mathrm{CD} 8^{+} \mathrm{T}$ cells (defined as CD62L low CD44 high) in draining lymph nodes (DLNs) as well as their functionality (IFN $\gamma$ and T-bet expression) and mitochondrial activation significantly increased in the group of responsive tumors, but did not change in unresponsive tumor-bearing hosts after PD-1 blockade. The unresponsiveness could be due to either i) no or low immune recognition and/or ii) systemic immunosuppression. To investigate the systemic immunosuppressive nature of unresponsive tumors, a "bilateral tumor inoculation model" was employed where unresponsive and responsive tumors were inoculated on different sides of the host. This model facilitates disclosing how much humoral factors derived from unresponsive tumors would contribute to the growth of responsive tumors in the other side. Using this model, LLC and CT26 were classified as unresponsive tumors with systemic immunosuppressive property (SIP) while B16 without SIP. Further, to understand immune recognition, tumor growth between wild type and immunocompromised host was compared. It is concluded that all responsive tumors are well immune recognized as they grow slower in immune sufficient (wild type) compared to immunocompromised host. On the contrary, some unresponsive tumor like B16, Wehi3 and Pan02 show no recognition while some unresponsive tumor like LLC, and CT26 show less immune recognition. In vivo analysis of bilateral tumor model suggests immunosuppression caused by unresponsive tumor inhibit $\mathrm{T}$ cells mitochondrial activation on the side bearing responsive tumor. To further this findings, effect of culture supernatant collected from cell lines were tested on $\mathrm{T}$ cells and it was found that proliferation and mitochondrial activation was attenuated when cultured in the presence of supernatant from SIP-positive tumor but not with SIP-negative tumor or responsive tumor. Analytical data suggests that the suppressive soluble factors are non-proteinaceous, small molecule (of size less than $3 \mathrm{KDa}$ ). Later, it was found that the suppression by SIP-positive tumor (LLC, CT26) was released to some extent by using mitochondrial activation chemicals (Bezafibrate, a pan-PPAR agonist) both in vitro (enhances proliferation and mitochondrial activation) and in vivo (reduced tumr size and improved survival). In summary, the unresponsiveness could be due to no/less immune recognition and immunosuppressive nature.
(論文審査の結果の要旨)

PD-1 阻害に基づくがん免疫チェックポイント療法はがん治療に革命をもたらし、 様々ながん種に適応されている。しかしながら、半数以上のがん患者はまだ不応答であ る。不応答性の原因は様々な様式があり、この原因を解明することが医学分野でも強く 求められている。 $\mathrm{T}$ 細胞のミトコンドリア代謝は T 細胞の分化や活性を制御しているた

め、腫瘍免疫の中心的な役割を担っている。

不応答性の原因として、がんが何らかの様式で $\mathrm{T}$ 細胞のミトコンドリア活性を抑制 しているという仮説を立てた。そこで不応答性のメカニズムを解明するため、不応答性 (unresponsive) および応答性（responsive）腫瘍を同じマウス宿主の両側に別々に接 種した。いくつかの unresponsive tumor ではPD-1 阻害中に反対側の responsive tumor の抗腫瘍効果を抑制することを見出した。この方法により、不応答性の原因を全 身性免疫抑制型（systemic immune suppression：SIP）と腫瘍局所免疫逃避型の二つに 分類することができた。SIP 陽性腫瘍のいくつかは(Luis lung cancer：LLC 等)、T 細 胞のミトコンドリア活性を直接阻害する非蛋白性低分子物質（〈3kDa）を放出し、結果 的に T 細胞増殖を阻害寸ることを見出した。一方でB16 メラノーマはSIP 陰性であり MHC 発現低下により免疫逃避を行っていた。またB16 のような SIP 陰性局所逃避型腫崵 に対してはミトコンドリア活性化剂による併用治療は無効であった。以上の研究は、不 応答性腫瘍が T 細胞のミトコンドリア抑制低分子物質を産生し、全身性免疫抑制を誘導 する新規免疫回避機構が存在することを示している。また不応答性を克服するため併用 治療を考える場合は、不応答性の原因様式に対応した治療戦略に寄与寸ると考えられ る。

したがって、本論文は博士（医学）の学位論文として価值のあるものと認める。 なお、本学位授与申請者は、令和 2 年 6 月 9 日実施の論文内容とそれに関連した 試問を受け、合格と認められたものである。 